\title{
Microstructure and Impression Creep Properties of Ca-Containing AS31 Magnesium Alloy
}

\author{
Mohammad Badri $^{1} \cdot$ Seyyed Mehdi Miresmaeili ${ }^{1} \cdot$ Bahram Nami $^{1}$
}

Received: 22 April 2016/Revised: 5 August 2016/Published online: 11 October 2016

(C) The Chinese Society for Metals and Springer-Verlag Berlin Heidelberg 2016

\begin{abstract}
The effect of $\mathrm{Ca}$ addition on the microstructure and impression creep properties of AS31 magnesium alloy was investigated in the current study. The results showed that the microstructure of AS31 alloy is composed of $\alpha(\mathrm{Mg})$ phase, massive $\mathrm{Mg}_{17} \mathrm{Al}_{12}$ and some Chinese script $\mathrm{Mg}_{2} \mathrm{Si}$ compounds. Addition of $2 \mathrm{wt} \% \mathrm{Ca}$ to AS31 alloy resulted in complete elimination of $\mathrm{Mg}_{17} \mathrm{Al}_{12}$ phase and formation of $\mathrm{Al}_{2} \mathrm{Ca}$ compound. Ca improved the alloy's creep properties especially at higher temperature. Improvement in the creep properties was attributed to the elimination of soft $\mathrm{Mg}_{17} \mathrm{Al}_{12}$ and formation of thermally stable $\mathrm{Al}_{2} \mathrm{Ca}$ compound. According to the obtained stress exponent and creep activation energy, pipe diffusion climb-controlled creep was estimated as the dominant creep mechanism and $\mathrm{Ca}$ had no influence on the dominant mechanism.
\end{abstract}

KEY WORDS: Magnesium-aluminum-silicon alloy; Calcium; Microstructure; Creep; Mechanism

\section{Introduction}

The applications of $\mathrm{Mg}-\mathrm{Al}$-based magnesium alloys have been limited to producing the parts serviced at the temperature less than $120^{\circ} \mathrm{C}$ since their mechanical and creep properties decrease at the higher temperatures [1]. Softening of $\mathrm{Mg}_{17} \mathrm{Al}_{12}$ phase in the alloys' microstructure is the main reasons which deteriorate the high-temperature mechanical properties of $\mathrm{Mg}-\mathrm{Al}$ alloys [2]. It has been shown that adding some alloying elements such as $\mathrm{Ca}, \mathrm{Sr}$, $\mathrm{Sb}$ and rare earth into $\mathrm{Mg}-\mathrm{Al}$ alloys can improve their creep properties. The enhanced creep properties of the alloys have been attributed to the formation of intermetallic compounds having high thermal stability [3-8].

Available online at http://link.springer.com/journal/40195

Seyyed Mehdi Miresmaeili

s.m.miresmaeili@srttu.edu

1 Shahid Rajaee Teacher Training University, Lavizan, Tehran, Iran
As well as the above-mentioned elements, $\mathrm{Si}$ is one of the most effective elements which improve creep resistance of $\mathrm{Mg}-\mathrm{Al}$ alloys [5]. The addition of $\mathrm{Si}$ to $\mathrm{Mg}-\mathrm{Al}$ alloys has resulted in developing $\mathrm{AS}(\mathrm{Mg}-\mathrm{Al}-\mathrm{Si})$ series alloys [9]. The improvement in the creep properties of AS alloys is ascribed to the presence of the highly thermally stable $\mathrm{Mg}_{2} \mathrm{Si}$ intermetallic compound in the alloy [9].

AS21 and AS41 are two standardized alloys among the AS series magnesium alloys being used in automotive engine parts [10]. AS21 alloy has better creep resistance than that of AS41, whereas AS41 alloy exhibits good casting characteristics and room temperature mechanical properties because of its higher Al content [11]. Meanwhile, AS31 alloy is a newly developed version of AS series magnesium alloy which exhibits a combination of good mechanical properties at low and high temperatures and reasonable die cast ability [12].

Results of previous studies have shown that $\mathrm{Ca}$ can improve the creep properties of $\mathrm{Mg}-\mathrm{Al}-\mathrm{Sr}$ [13], $\mathrm{Mg}-\mathrm{Al}-$ $\mathrm{Mn}$ [14], Mg-Al-Sn [15], Mg-Zn-Sn [16], Mg-Al-RE [17] and $\mathrm{Mg}-\mathrm{Sn}$ [18] alloys. It has been reported that $\mathrm{Ca}$ addition can enhance the creep properties of those alloys as a result of the formation of highly thermally stable Ca-rich compounds such as $\mathrm{Al}_{2} \mathrm{Ca},(\mathrm{Mg}, \mathrm{Al})_{2} \mathrm{Ca}$ and $\mathrm{Mg}_{2} \mathrm{Ca}$ in the 
Table 1 Chemical composition of the alloys (wt $\%)$

\begin{tabular}{lllll}
\hline Alloy & $\mathrm{Al}$ & $\mathrm{Si}$ & $\mathrm{Ca}$ & $\mathrm{Mg}$ \\
\hline AS31 & 3.04 & 0.85 & - & $\mathrm{Bal}$. \\
ASX311 & 3.12 & 0.87 & 1.06 & $\mathrm{Bal}$. \\
ASX312 & 3.06 & 0.91 & 1.84 & $\mathrm{Bal}$. \\
\hline
\end{tabular}

microstructures [13, 17, 19]. Due to low solubility of $\mathrm{Ca}$ in $\mathrm{Mg}-\mathrm{Al}$ alloys, these thermally stable second phases usually precipitate along grain boundaries in the as-cast alloys [20]. It was noted that the $\beta-\mathrm{Mg}_{17} \mathrm{Al}_{12}$ intermetallic phase suffers severe cracking and facilitates cavity formation due to its low melting point and incoherency with $\mathrm{Mg}$ matrix, which results in poor creep resistance [21]. Ca improves creep properties of $\mathrm{Mg}-\mathrm{Al}$ alloys either by reducing the amount of $\mathrm{Mg}_{17} \mathrm{Al}_{12}$ phase or by increasing its melting point $[5,8]$. Considering the above effect of $\mathrm{Ca}$ on the microstructure of $\mathrm{Mg}-\mathrm{Al}$ alloys, it is predicted that $\mathrm{Ca}$ may improve the creep properties of AS series alloys. Despite the advantages of $\mathrm{Ca}$ addition to $\mathrm{Mg}-\mathrm{Al}$ alloys, its effect on the creep properties of AS31 alloy has not been studied so far. Therefore, the aim of this study is to investigate the effect of $\mathrm{Ca}$ addition on the microstructure and creep properties of AS31 magnesium alloy.

\section{Experimental}

Three Mg-3Al-1Si- $x$ Ca alloys, chemical compositions of which are presented in Table 1, were prepared using commercial pure $\mathrm{Mg}, \mathrm{Al}, \mathrm{Si}$ and $\mathrm{Ca}$ in the current study. Melting
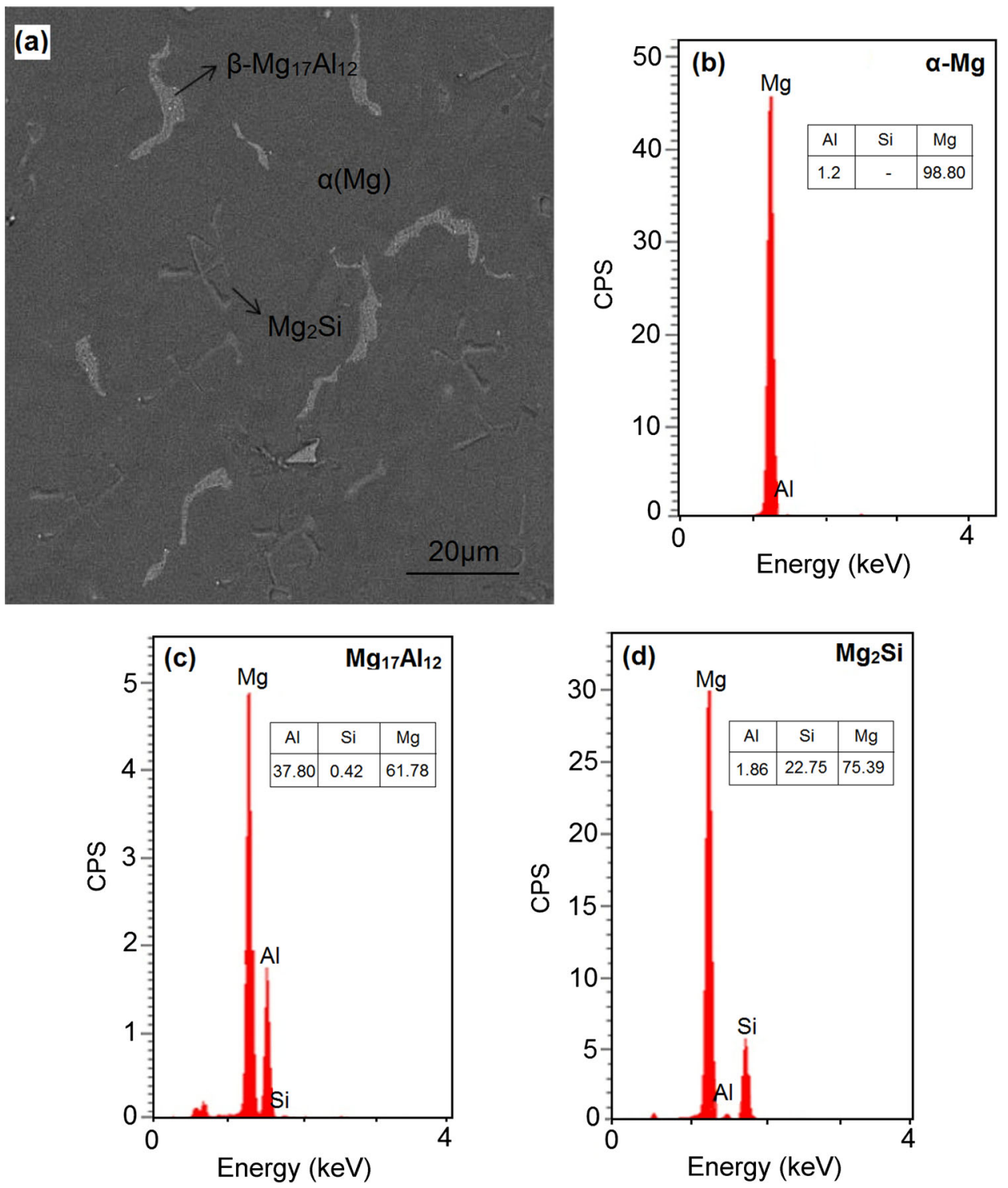

Fig. 1 SEM image of AS31 alloy accompanied with EDS spectrum of the phases shown with arrows 

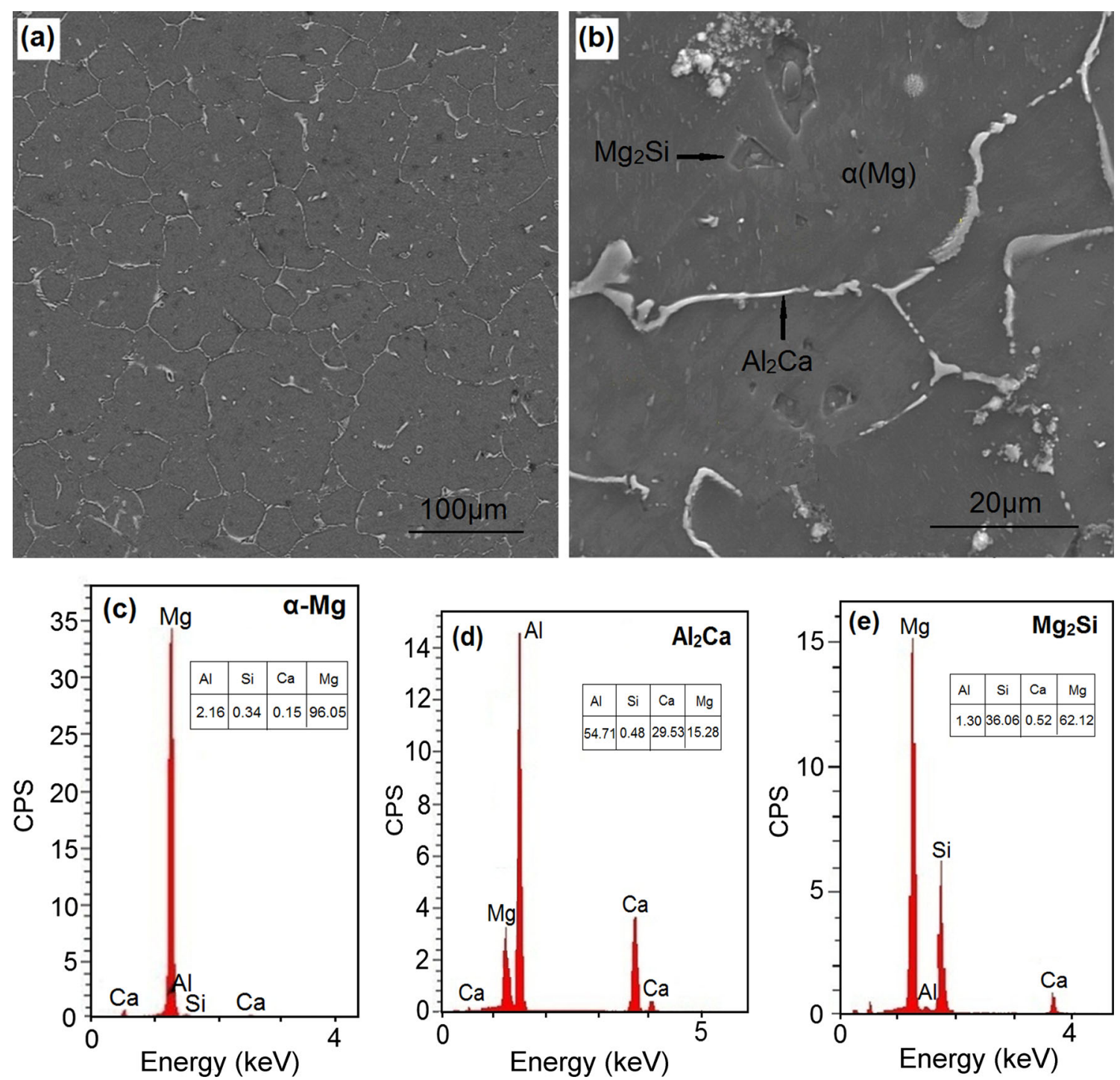

Fig. 2 SEM image of ASX312 alloy with two different magnifications accompanied with EDS analysis

of the alloys was carried out in a graphite crucible inside an electrical resistance furnace under protection of argon atmosphere. The alloys' melt was stirred by a steel rod for $5 \mathrm{~min}$ and held isothermally at $1023 \mathrm{~K}$ for $30 \mathrm{~min}$. After that, it was poured in a rectangular steel mold with dimension of $300 \mathrm{~mm} \times 120 \mathrm{~mm} \times 10 \mathrm{~mm}$ preheated to $423 \mathrm{~K}$. Samples with dimension of $12 \mathrm{~mm} \times 10 \mathrm{~mm} \times 8 \mathrm{~mm}$ were cut and then machined from the cast ingots. Two parallel surfaces of the specimens were ground using abrasive papers with grit numbers from 80 to 600 . Creep properties of the specimens were examined under stress values of 200 to $500 \mathrm{MPa}$ at the temperatures between 423 and $491 \mathrm{~K}$ for $5000 \mathrm{~s}$ using impression creep technique. A cylindrical punch with diameter of $2 \mathrm{~mm}$ was used for the impression creep investigations.

Samples of the alloys were prepared for microstructural studies using abrasive papers grit number of 80-2500.
Final polishing was carried out by $1-\mu \mathrm{m}$ diamond paste. Microstructural investigations of the samples were performed using VEGA-Tescan scanning electron microscope equipped with EDAX.

\section{Results and Discussion}

\subsection{As-Cast Microstructure}

Figure 1 shows the SEM image of AS31 alloy accompanied by the EDS spectra obtained from the different phases shown by arrow. As shown in Fig. 1a, microstructure of AS31 alloy is composed of primary $\alpha(\mathrm{Mg})$ phase and two types of intermetallic compounds which have been distributed in the interdendritic regions. Chemical composition of the compounds shows that they may be $\mathrm{Mg}_{17} \mathrm{Al}_{12}$ 


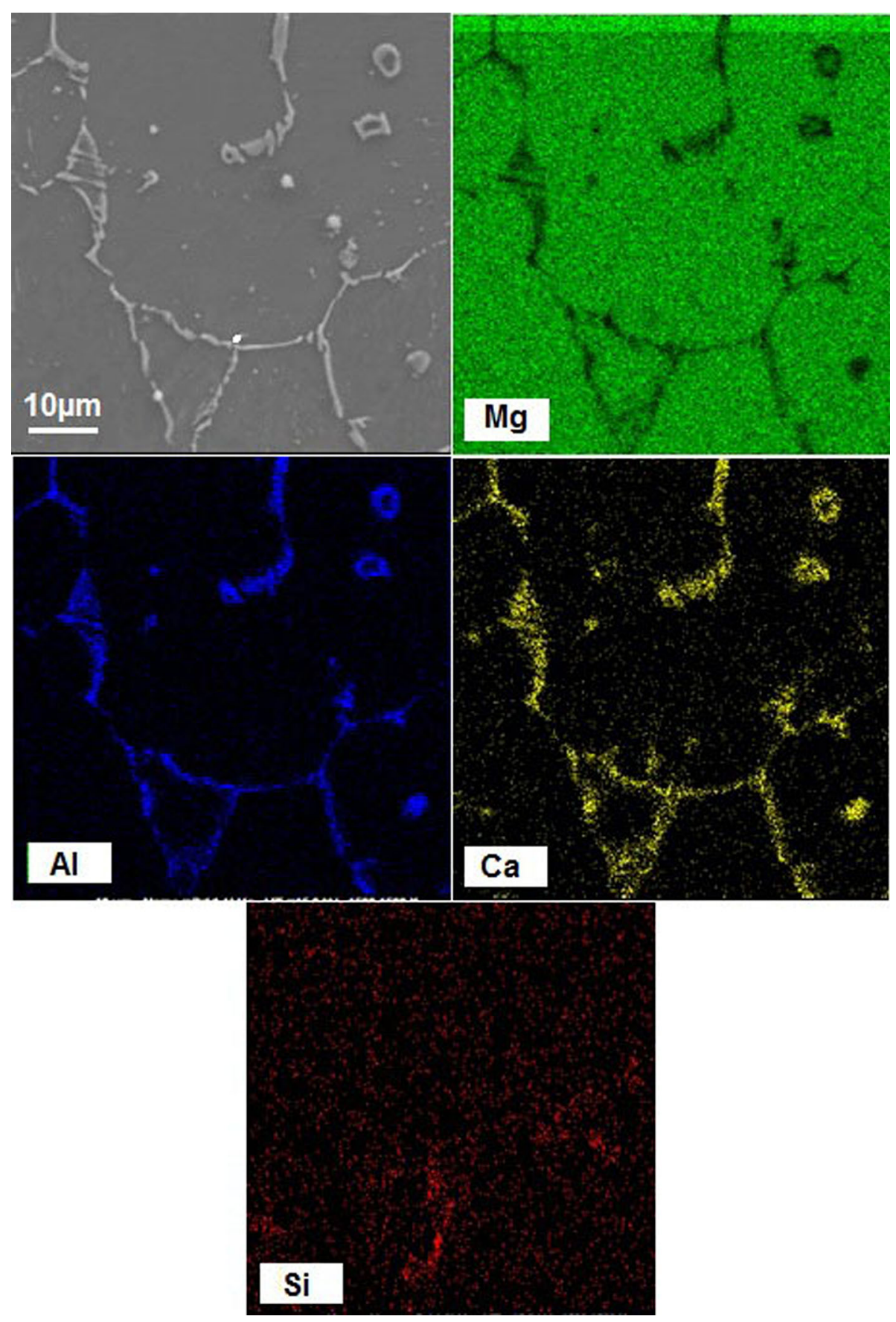

Fig. 3 Elemental maps of the alloying elements in ASX312 alloy

and $\mathrm{Mg}_{2} \mathrm{Si}$ as it can be predicted from the $\mathrm{Mg}-\mathrm{Al}-\mathrm{Si}$ ternary phase diagram. According to the previous investigation, microstructure constituents of AS series Mg alloys are $\alpha(\mathrm{Mg}), \mathrm{Mg}_{17} \mathrm{Al}_{12}$ and $\mathrm{Mg}_{2} \mathrm{Si}$ intermetallic compounds $[9,11,12]$. It is apparent in Fig. 1a that $\mathrm{Mg}_{2} \mathrm{Si}$ has Chinese script morphology. The results of microanalysis reveal that Si has no solubility in the matrix phase; however, it dissolves slightly in $\mathrm{Mg}_{17} \mathrm{Al}_{12}$ compound.
Figure 2 shows the SEM image of ASX312 alloy. As seen, the microstructure of this alloy has been changed completely with $\mathrm{Ca}$ addition. It is clear that a new semicontinuous compound has been formed around the primary $\alpha(\mathrm{Mg})$ dendrites. It is also noteworthy that $\mathrm{Ca}$ has changed the morphology of Si-rich phase from Chinese script to the polygonal form. EDS spectra and the relevant chemical composition obtained from the different phases 

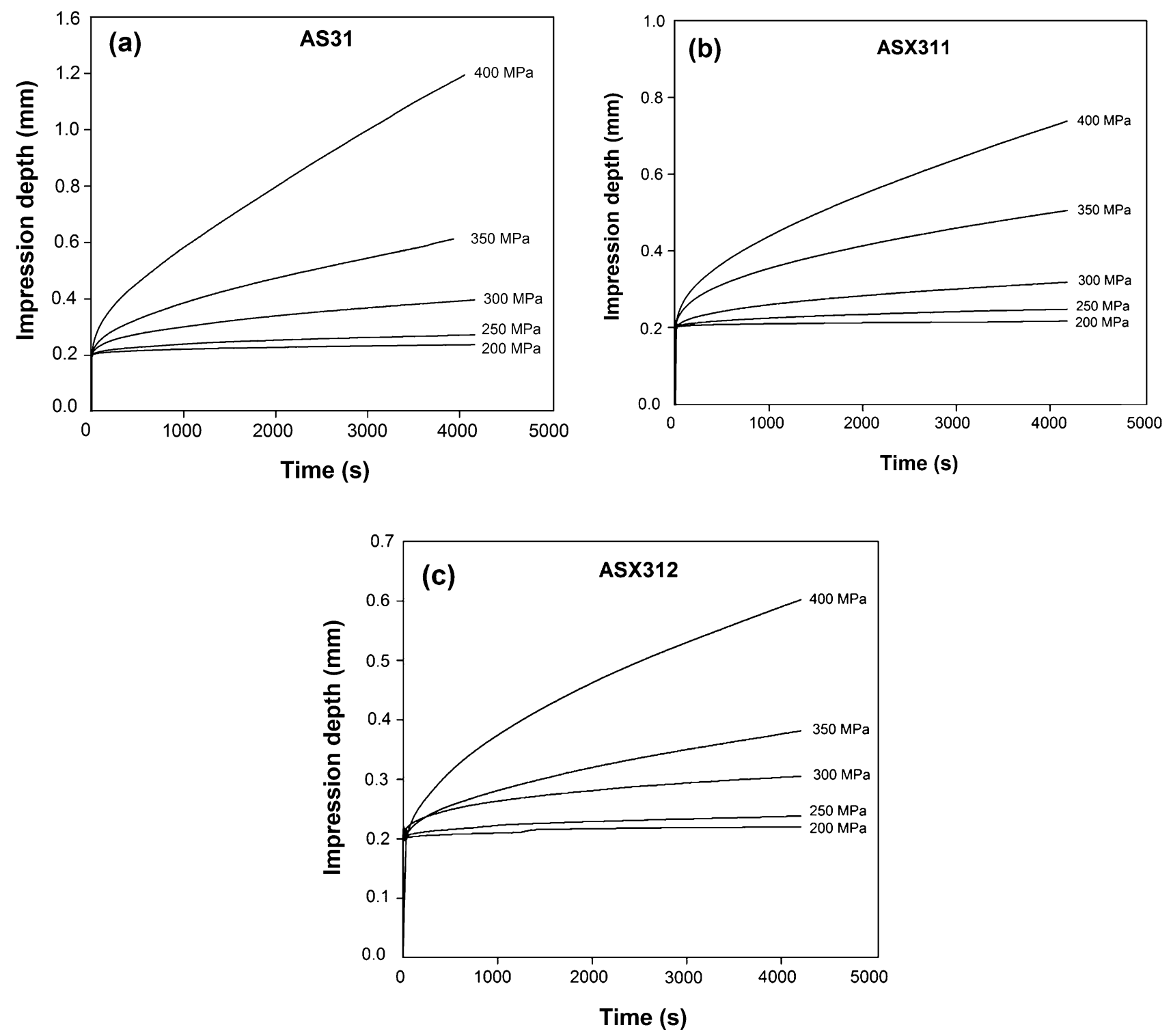

Fig. 4 Plots of impression depth versus time at $476 \mathrm{~K}$ for a AS31, b ASX311, c ASX312

in Fig. $2 b$ are shown in Fig. $2 c$, d, e. According to the results of EDS microanalysis, $\mathrm{Si}$ and $\mathrm{Ca}$ are dissolved slightly in the matrix phase. The chemical composition of the semi-continuous bright phase in the interdendritic regions in Fig. $2 \mathrm{~b}$ indicates that this $\mathrm{Ca}$ - and Al-rich phase may be $\mathrm{Al}_{2} \mathrm{Ca}$ compound. It has been shown that addition of $\mathrm{Ca}$ to $\mathrm{Mg}-\mathrm{Al}$ alloys can form $\mathrm{Al}_{2} \mathrm{Ca}, \mathrm{Mg}_{2} \mathrm{Ca}$ and $(\mathrm{Mg}, \mathrm{Al})_{2} \mathrm{Ca}$ compounds in the alloy [8, 13]. Ninimiya et al. [22] have reported that the type of Ca-rich compounds in $\mathrm{Mg}-(3-9) \mathrm{wt} \% \mathrm{Al}-(1-5) \mathrm{wt} \% \mathrm{Ca}$ alloys depends on the ratio of $\mathrm{Ca} / \mathrm{Al} . \mathrm{Mg}_{2} \mathrm{Ca}$ and $\mathrm{Al}_{2} \mathrm{Ca}$ are formed at the ratios more than 0.8 , while $\mathrm{Al}_{2} \mathrm{Ca}$ is the only compound in the alloys with the lower ratios [22]. Considering the ratio in ASX312 alloy (about 0.66), it can be concluded that this new bright phase is $\mathrm{Al}_{2} \mathrm{Ca}$ intermetallic compound.

Figure 3 illustrates the X-ray dot maps of the different elements in the microstructure of ASX312 alloy. The elemental maps indicate that the Ca-containing phase is $\mathrm{Al}_{2}$ Ca. As shown in Figs. 2, 3, $\mathrm{Mg}_{17} \mathrm{Al}_{12}$ phase has been eliminated in the ASX312 alloy due to Ca addition which is in good agreement with those reported for the similar alloys $[8,23]$. It has been indicated in many publication that high chemical affinity between $\mathrm{Ca}$ and $\mathrm{Al}$ in comparison with that between $\mathrm{Ca}$ and $\mathrm{Mg}$ results in formation of very stable intermetallic compounds of $\mathrm{Al}_{2} \mathrm{Ca}$ instead of $\mathrm{Mg}_{17} \mathrm{Al}_{12}$ compound [24]. Considering the forming temperature of $\mathrm{Al}_{2} \mathrm{Ca}$ compound which is higher than that of 

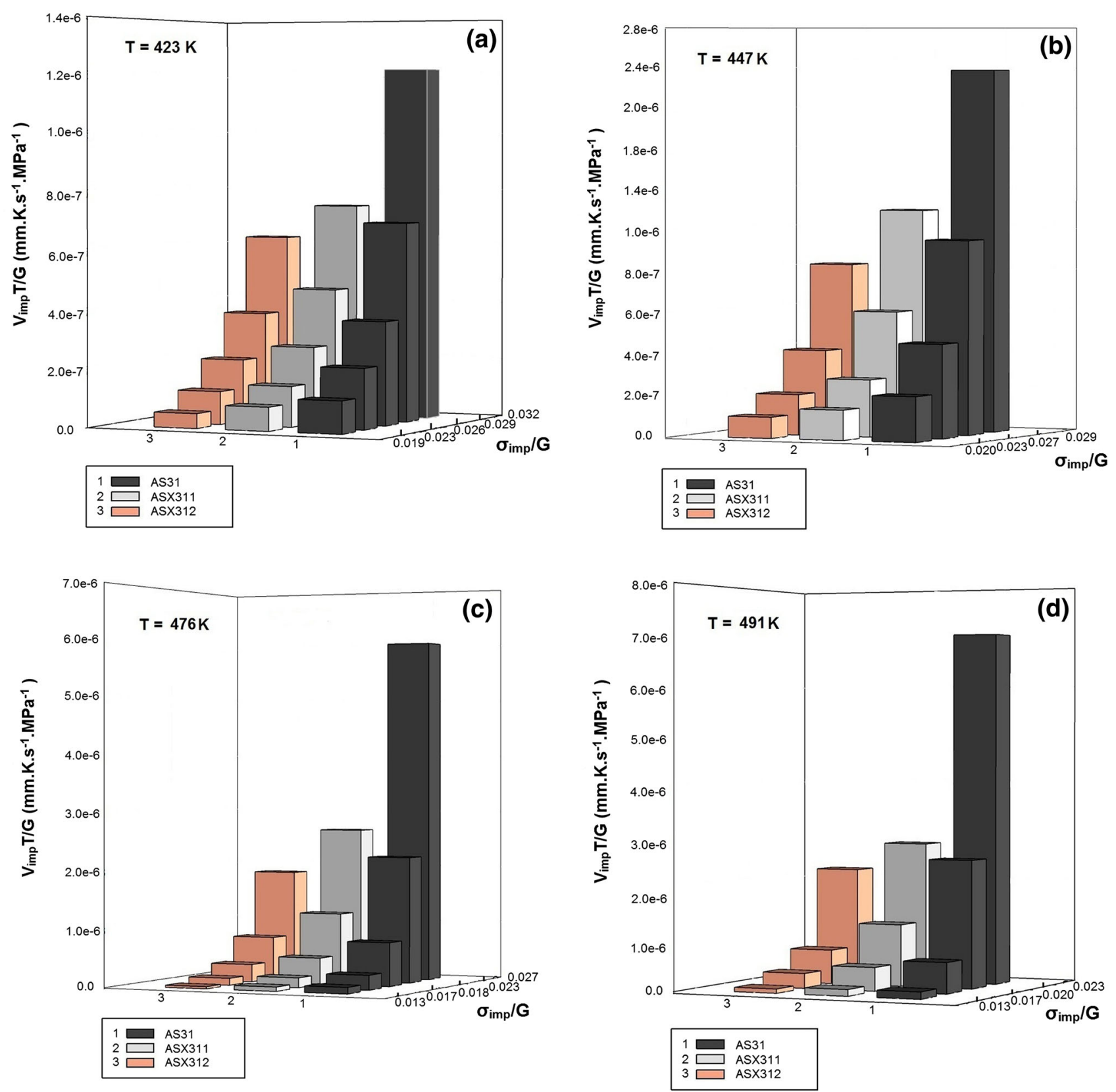

Fig. 5 Comparison of minimum creep rates obtained at different normalized stresses at a $423 \mathrm{~K}$, b $447 \mathrm{~K}$, c $476 \mathrm{~K}$, d $491 \mathrm{~K}$

$\mathrm{Mg}_{17} \mathrm{Al}_{12}$ phase [25] and the stoichiometry formula of $\mathrm{Al}_{2} \mathrm{Ca}$, it is concluded that $\mathrm{Ca}$ consumes the entire $\mathrm{Al}$ atoms in $\mathrm{ASX} 312$ alloy through the formation of $\mathrm{Al}_{2} \mathrm{Ca}$ compound.

\subsection{Impression Creep Behavior}

Impression creep curves of the alloys crept at $476 \mathrm{~K}$ under different stress values are shown in Fig. 4. It is obvious that the creep curves are composed of two primary and steady-state regimes. Comparing the curves indicates that the final impression depth has reverse relation with $\mathrm{Ca}$ content under the different test conditions. For instance, the final impression depths for AS31, ASX311 and ASX312 under $400 \mathrm{MPa}$ are about 1.2, 0.8 and $0.6 \mathrm{~mm}$, respectively, implying that the creep properties of AS31 alloy improves noticeably with increasing $\mathrm{Ca}$ amount.

Figure 5 shows the variation of normalized steady-state impression velocity versus shear modulus normalized stress at different temperatures. The impression velocities were obtained from slope of the linear region of the creep curves. Shear modulus of the alloys were calculated using the following equation [26]. 

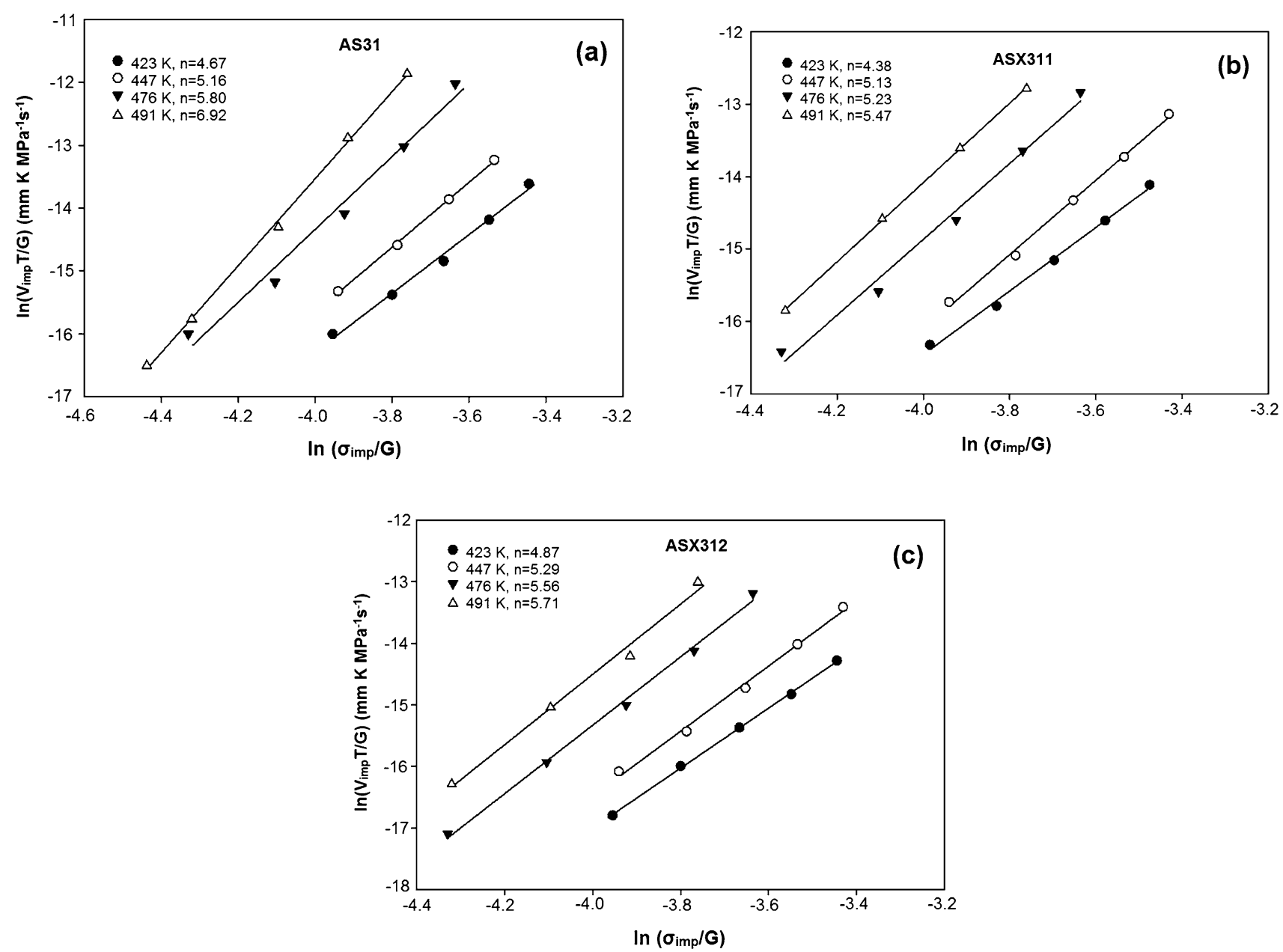

Fig. 6 Variation of $\ln \left(V_{\mathrm{imp}} T / G\right)$ versus $\ln \left(\sigma_{\mathrm{imp}} / G\right)$ at constant $T$ for calculating the stress exponent: a AS31 alloy, b ASX311 alloy, c ASX312 alloy

$G(\mathrm{MPa})=15400-18(T(\mathrm{~K})-400)$.

The figures reveal that the impression velocity is reduced with $\mathrm{Ca}$ addition under all conditions, indicating that the Ca-containing alloys have better creep properties in comparison with AS31 alloy. The improvement in creep properties is more pronounced at the higher test temperatures.

\subsection{Creep Mechanism}

The main reason for improving creep properties of the alloys due to the $\mathrm{Ca}$ addition can be clarified by estimating the dominant creep mechanism. For this purpose, it is needed to obtain the stress exponent $(n)$ and creep activation energy $\left(Q_{\mathrm{c}}\right)$ from the following power law equation [8]

$\left(\frac{V_{\mathrm{imp}} T}{G}\right)=A\left(\frac{\sigma_{\mathrm{imp}}}{G}\right)^{n} \exp \left(\frac{-Q_{\mathrm{c}}}{R T}\right)$. where $V_{\text {imp }}$ is the minimum impression velocity, $T$ is the test temperature in Kelvin, $A$ is constant, $\sigma_{\text {imp }}$ is the applied stress, and $R$ is the gases universal constant.

According to Eq. (2), the stress exponent and creep activation energy can be obtained from the slope of variation of $\ln \left(V_{\mathrm{imp}} T / G\right)$ versus $\ln \left(\sigma_{\mathrm{imp}} / G\right)$ at constant temperature and slope of variation of $\ln \left(V_{\mathrm{imp}} T / G\right)$ versus 1/ $T$ under constant stress, respectively. Figure 6 shows the variation of $\ln \left(V_{\mathrm{imp}} T / G\right)$ versus $\ln \left(\sigma_{\mathrm{imp}} / G\right)$ at different testing temperatures. Slopes of the lines shown in the figures reveal that the values of stress exponent are between 4.38 and 6.92. It is seen that the stress exponents are similar at the lower temperature for all the alloys, whereas its value is decreased with $\mathrm{Ca}$ addition at the higher temperatures. Comparison of the obtained values of $n$ with those reported in the literature $[8,27]$ indicates that climbcontrolled dislocation creep is the dominant mechanism for the creep of the alloys. 

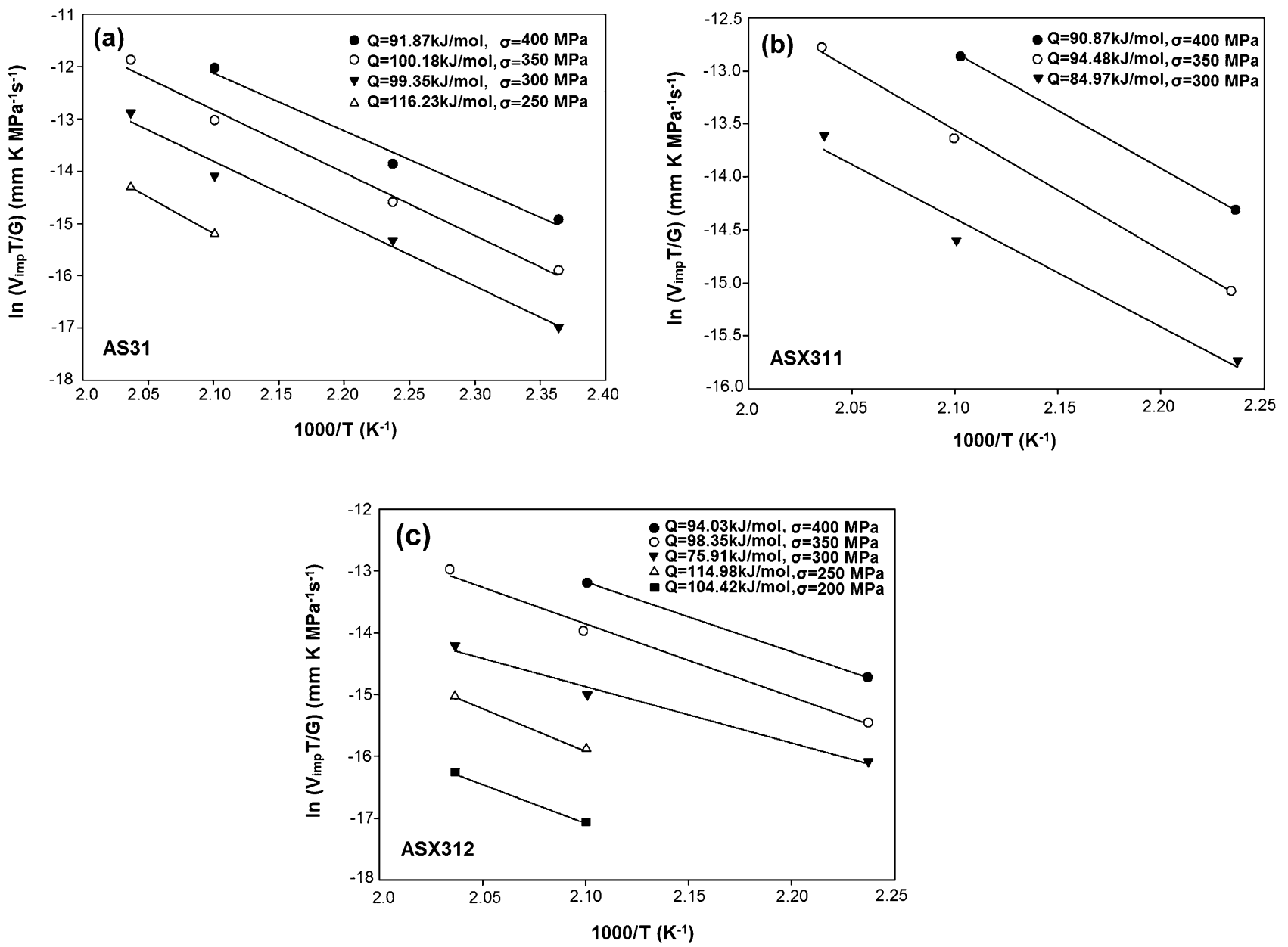

Fig. 7 Variation of $\ln \left(V_{\text {imp }} T / G\right)$ versus $1000 / T$ at constant stresses for determining Q-values: a AS31, b ASX311, c ASX312

Figure 7 shows the variation of $\ln \left(V_{\mathrm{imp}} G / T\right)$ versus $1 /$ $T$ under constant stress values which were used for calculating creep activation energy. It can be seen that the creep activation energy are between 84 and $116 \mathrm{~kJ} / \mathrm{mol}$. It is obvious that $\mathrm{Ca}$ has no considerable effect on the creep activation energy. The obtained values are close to the dislocation pipe diffusion activation energy of $\mathrm{Mg}$ atoms, indicating that the velocity of dislocation climbing is controlled by Mg pipe diffusion.

The obtained stress exponent and creep activation energies reveal that pipe diffusion climb-controlled dislocation creep is the dominant mechanism for the creep of three alloys. This mechanism can clarify the reasons for improving creep properties of AS31 alloy with Ca addition. It is known that the main reasons for the high creep rate of magnesium alloys are dislocation slip and grain boundary slide at both basal and non-basal planes of magnesium. Hence, in order to develop high-temperature magnesium alloys, obstructing the dislocation slip and grain boundary slide through incorporating thermally stable hard phases at the grain boundary or within the grain becomes a key approach [28].

Therefore, creep properties of the alloys in climb-controlled dislocation creep can be improved either by eliminating soft intermetallic compounds having low melting point or by formation of new compounds having high thermal stability $[8,15,26]$. Also, age hardening may have constructive effect on the creep properties [29]. Reducing stacking fault energy due to dissolved alloying elements in the matrix phase is the other approach which enhances the alloys creep properties [30]. As shown in Fig. $1, \mathrm{Mg}_{17} \mathrm{Al}_{12}$ intermetallic compound is distributed in the interdendritic regions of the AS31 alloy. Softening of $\mathrm{Mg}_{17} \mathrm{Al}_{12}$ compound at the temperatures more than $120{ }^{\circ} \mathrm{C}$ is the main reason for poor creep properties of $\mathrm{Mg}-\mathrm{Al}$ alloys [29]. Thus, the easy grain boundary sliding along the network of soft $\mathrm{Mg}_{17} \mathrm{Al}_{12}$ phase reduces creep properties of $\mathrm{AS} 31$ alloy. In this condition, it is expected that substitution of high-melting point $\mathrm{Al}_{2} \mathrm{Ca}$ compounds $\left(1079{ }^{\circ} \mathrm{C}\right)$ for lowmelting point $\mathrm{Mg}_{17} \mathrm{Al}_{12}$ phase $\left(460^{\circ} \mathrm{C}\right)$ can be the main 
reason for enhancing the creep properties of the Ca-containing alloys.

As reported above, reducing stacking faults energy may be the reason which can improve the creep properties of Ca-containing alloy. Chemical composition of the $\mathrm{Mg}$ matrix phase of ASX312 alloy in Fig. 2 reveals that Ca has been slightly dissolved in the matrix phase of ASX312 alloy. It has been reported that the stacking fault energy of $\mathrm{Mg}$ reduces with increasing Ca content [31] which partly improves the alloy creep properties.

\section{Conclusions}

The effect of $\mathrm{Ca}$ addition on the microstructure and impression creep properties of AS31 magnesium alloy was investigated in the current study. The impression creep test was performed under stress values between 200 and $500 \mathrm{MPa}$ at temperature ranging from 423 to $491 \mathrm{~K}$. The following results were obtained:

1 The microstructure of AS31 alloy is composed of $\alpha(\mathrm{Mg})$ phase, massive $\mathrm{Mg}_{17} \mathrm{Al}_{12}$ and Chinese script $\mathrm{Mg}_{2} \mathrm{Si}$ compounds.

$2 \mathrm{Ca}$ addition may eliminate $\mathrm{Mg}_{17} \mathrm{Al}_{12}$ phase in the AS31 alloy and changes the morphology of $\mathrm{Mg}_{2} \mathrm{Si}$ phase to polygonal morphology. Formation of semi-continuous $\mathrm{Al}_{2} \mathrm{Ca}$ in the interdendritic regions is the other effect of $\mathrm{Ca}$ on the microstructure of AS31 alloy.

$3 \mathrm{Ca}$ addition may improve the creep properties of AS31 alloy especially at the higher temperatures. The improvement in the creep properties was ascribed to the elimination of $\mathrm{Mg}_{17} \mathrm{Al}_{12}$ compound and formation of $\mathrm{Al}_{2} \mathrm{Ca}$ intermetallic compounds.

4 The stress exponent and creep activation energy of the alloys varied between 4.38-6.92 and 84-116, respectively, revealing that pipe diffusion climb-controlled dislocation creep is the dominant mechanism. Ca addition has no influence on the dominant mechanism.

\section{References}

1. L. Han, D.O. Northwood, X. Nie, H. Hu, Mater. Sci. Eng. A 512, 58 (2009)

2. Y.Z. Lü, Q.D. Wang, X.Q. Zeng, W.J. Ding, Y.P. Zhu, Mater. Sci. Technol. 17, 207 (2001)
3. A. Srinivasan, J. Swaminathan, M.K. Gunjan, U.T.S. Pillai, B.C. Pai, Mater. Sci. Eng. A 527, 1395 (2010)

4. Q. Wang, W. Chen, X. Zeng, Y. Lu, W. Ding, Y. Zhu, X. Xu, J. Mater. Sci. 36, 3035 (2001)

5. F. Xue, X. Min, Y. Sun, J. Mater. Sci. 41, 4725 (2006)

6. P. Zhao, Q. Wang, C. Zhai, Y. Zhu, Mater. Sci. Eng. A 444, 318 (2007)

7. Y. Guangyin, S. Yangshan, Z. Weiming, J. Mater. Sci. Lett. 18, 2055 (1999)

8. B. Nami, H. Razavi, S. Mirdamadi, S.G. Shabestari, S.M. Miresmaeili, Metall. Mater. Trans. A 41, 1973 (2010)

9. M.S. Dargusch, A.L. Bowles, K. Pettersen, P. Bakke, G.L. Dunlop, Metall. Mater. Trans. A 35, 1905 (2004)

10. J.W. Wang, J.X. Zhou, B.C. Ma, S.Q. Tang, F.M. Chu, Y.S. Yang, Appl. Mech. Mater. 697, 67 (2014)

11. S.M. Zhu, M.A. Easton, M.A. Gibson, M.S. Dargusch, J.F. Nie, Mater. Sci. Eng. A 578, 377 (2013)

12. V.V. Agalakov, in Magnesium: ed. by K.U. Kainer. Proceedings of the 6th International Conference Magnesium Alloys and Their Applications, (Wiley-VCH, Germany, 2004), p. 19

13. B. Jingaa, S. Yangshana, X. Shana, X. Fenga, Z. Tianbai, Mater. Sci. Eng. A 419, 181 (2006)

14. D. Itoh, Y. Terada, T. Sato, Mater. Trans. 49, 1957 (2008)

15. B.H. Kim, K.C. Park, Y.H. Park, I.M. Park, Trans. Nonferrous Met. Soc. China 20, 1184 (2010)

16. M.B. Yang, L. Cheng, F.S. Pan, Trans. Nonferrous Met. Soc. China 20, 769 (2010)

17. Y. Zhang, L. Yang, J. Dai, J. Ge, G. Guo, Z. Liu, Mater. Des. 63, 439 (2014)

18. G. Nayyeri, R. Mahmudi, F. Salehi, Mater. Sci. Eng. A 527, 5353 (2010)

19. A.A. Luo, M.P. Balogh, B.R. Powell, Metall. Mater. Trans. A 33, $567(2002)$

20. K. Shu, K.K. Deng, F.J. Xu, K.B. Nie, L. Zhang, X. Zhang, W.J. Li, Acta Metall. Sin. (Engl. Lett.) 28, 1015 (2015)

21. A.F.A.E. Rehim, Acta Metall. Sin. (Engl. Lett.) 28, 1065 (2015)

22. R. Ninomiya, T. Ojiro, K. Kubota, Acta Metall. Mater. 43, 669 (1995)

23. Y. Nakaura, A. Watanabe, K. Ohori, Mater. Trans. 47, 1031 (2006)

24. A. Suzuki, N.D. Saddock, J.W. Jones, T.M. Pollock, Acta Mater. 53, 2823 (2005)

25. K. Ozturk, Y. Zhong, A. Luo, Z. Liu, JOM 55, 40 (2003)

26. E.M. Mazraeshahi, B. Nami, S.M. Miresmaeili, S.M. Tabatabaei, Mater. Des. 76, 64 (2015)

27. S.R. Agnew, K.C. Liu, E.A. Kenik, S. Viswanathan, in Magnesium Technology 2000, ed. by H.I. Kaplan, J.N. Hryn, B.B. Clow (TMS, Warrendale, PA, 2000), pp. 285-290

28. L. Chen, Y. Yao, Acta Metall Sin. (Engl. Lett.) 27, 762 (2014)

29. B. Nami, H. Razavi, S.M. Miresmaeili, S. Mirdamadi, S.G. Shabestari, Scr. Mater. 65, 221 (2001)

30. B. Amir Esgandari, B. Nami, M. Shahmiri, A. Abedi, Trans. Nonferrous Met. Soc. China 23, 2518 (2014)

31. W.Y. Wang, S.L. Shang, Y. Wang, Z.G. Mei, K.A. Darling, L.J. Kecskes, S.N. Mathaudhu, X.D. Hui, Z.K. Liu, Mater. Res. Lett. 2, 29 (2014) 